\title{
Phenotypic evaluation of trait types in Guzerá cows of different calving orders
}

\section{Avaliação fenotípica das características de tipo de vacas Guzerá em diferentes ordens de parto}

\author{
Dorgival Morais de Lima Júnior ${ }^{1 *}$; Adriano Henrique do Nascimento Rangel²; \\ Guilherme Ferreira da Costa Lima ${ }^{3}$; Lúcio Flávio Macedo Mota ${ }^{4}$; Gelson dos \\ Santos Difante ${ }^{2}$; Stela Antas Urbano ${ }^{2}$; Waldonys Moreira Pinheiro ${ }^{5}$
}

\begin{abstract}
The objective of this study was to evaluate the effect of parity on linear trait types in Guzerá cows using multivariate techniques. Data were collected from 68 purebred Guzera females, young $\left(1^{\text {st }}\right.$ and $2^{\text {nd }}$ calving order) and adults ( $3^{\text {rd }}$ to $7^{\text {th }}$ calving order). Measurements were collected using a tape measure, a hypometer, a $40 \mathrm{~cm}$ graduated ruler and a $180^{\circ}$ protractor. $\mathrm{PRCOMP}$ procedure of the R program was used for analyzing the main components. The variables related to rump (height, angularity, ileum and ischium length and width), body (length), udder (height of posterior ligament) and milk production were more important to explain the phenotypic variation in Guzerá cattle. Young Guzerá cows had lower body length, narrower rumps, better udder ligaments and lower milk yield than adult cows.
\end{abstract}

Key words: Dairy cattle. Multivariate. Zebu cattle.

\section{Resumo}

Objetivou-se avaliar a efeito da ordem de parto, por meio de técnicas multivariadas, sobre as características lineares de tipo de vacas da raça Guzerá. Foram utilizados dados de 68 fêmeas da raça Guzerá, puras de origem, jovens ( $1^{\mathrm{a}}$ e $2^{\mathrm{a}}$ ordem de parto) e adultas ( $3^{\mathrm{a}}$ a $7^{\mathrm{a}}$ ordem de parto $)$. As medidas foram coletadas com auxílio de fita métrica, hipômetro, régua graduada de $40 \mathrm{~cm}$ e transferidor de ângulos $180^{\circ}$. Para as análises de componentes principais utilizou-se o procedimento PRCOMP do programa R. As variáveis relacionadas à garupa (altura, angulosidade, comprimento e largura de íleo e ísquios), corpo (comprimento), úbere (altura do ligamento posterior) e produção de leite apresentaram maior importância para explicar a variação fenotípica de bovinos Guzerá. Vacas jovens da raça Guzerá apresentaram menor comprimento corporal, garupas mais estreitas, melhores ligamentos de úbere e menor produção de leite que as vacas adultas.

Palavras-chave: Bovinocultura leiteira. Multivariada. Zebuínos.

Prof. Adjunto, Universidade Federal de Alagoas, UFAL, Arapiraca, AL, Brasil. E-mail: juniorzootec@yahoo.com.br

2 Profs. Associados, Universidade Federal do Rio Grande do Norte, UFRN, Macaíba, RN, Brasil. E-mail: adrianohrangel@yahoo. com.br; gdifante@ufrn.br; stela antas@yahoo.com.br

${ }^{3}$ Pesquisador, Empresa de Pesquisa Agropecuária do Rio Grande do Norte, EMPARN, Natal, RN, Brasil. E -mail: guilhermelima@, yahoo.com.br

4 Discente, Curso de Doutorado, Programa de Pós-Graduação em Zootecnia, Universidade Estadual Paulista, UNESP, Jaboticabal, SP, Brasil. E -mail: flaviommota.zoo@gmail.com

5 Discente, Curso de Mestrado, Programa de Pós-Graduação em Zootecnia, UFAL, Rio Largo, AL, Brasil. E -mail: waldonysmoreira@gmail.com

* Author for correspondence

Received: Nov. 24, 2016 Approved: May 17, 2017 


\section{Introduction}

The production of bovine milk in Brazil was 35.2 billion liters in 2014 (IBGE, 2015). It is estimated that three quarters of this milk is produced by females with some zebuine genetic traits. In this context, the Guzerá breed stands out due to its high size, rusticity and well-proportioned udder (LEÃO et al., 2013). This breed has officially been improved since 1994, when Embrapa instituted the Guzerá National Milk Improvement Program.

Dairy breeding programs have used the highest 305-day cumulative milk production for many years as the main, if not the only parameter for genetic evaluation of herds (HERRERA et al., 2008). However, the emphasis on selection for milk production has led to a decline in indicators of fertility, longevity and hygiene of dairy herds, due to unfavorable genetic correlation between these two groups of characteristics (RODRIGUEZMARTINEZ et al., 2008).

Currently, there is a search for animals are not only productive, but also have functional characteristics such as fertility and resistance to diseases, since these are extremely important for female longevity. Trait types should be considered when the objective is to maximize the productive life of the animal, avoiding early rejects due to non-productive problems related to attachment and ligaments, among others (ESTEVES et al., 2004; LAGROTTA et al., 2010).

Thus, an alternative to promote cow sustainability in productive life would be to select them based on trait types, since there is evidence that some of these traits are genetically and favorably related to longevity, functionality and productivity in dairy herds (PÉREZ-CABRAL et al., 2006). Moreover, factors such as age and calving order influence trait types, since females tend to undergo changes in their body structure (MUNIZ et al., 2014; MARIZ et al., 2016).
Thus, the objective of this study was to evaluate the effect of parity on types of linear traits of Guzerá cows using multivariate techniques.

\section{Material and Methods}

The work was conducted according to ethical standards and approved by the Ethics Committee for the Use of Animals (CEUA) of the Federal University of Rio Grande do Norte (UFRN), Brazil - CEUA License 028/2015.

Data came from 68 purebred Guzerá females, participants of the National Improvement Program of Guzerá Milk in 2009. The evaluated cows were primiparous (young) and multiparous (adult), from the first to seventh calving order, with ages varying from 04 to 12 years. The animals were positioned with their head upright and their four members resting on a flat surface to measure their body characteristics. The measurements were collected with the aid of a tape measure, a hypometer, a $40-\mathrm{cm}$ graduated ruler, and a $180^{\circ}$ protractor (VERNEQUE et al., 2014).

The following measurements were taken: Front udder height (FHT); Rear udder height (RHT); Rump height (RHT); Rump angle (RAG); Rear hoof angle (RHAG); Front udder height (FUH); Front teat length (FOL); Rump length (RL); Body length (LEN); Rear teat length (REL); Navel length (NAL); Front teat diameter (FOD); Rear teat diameter (RED); Ilium width (ILWI); Ischium width (ISWI); Anterior ligament (score 1 to 9) (AL); Rear udder width (RUW); Thoracic perimeter (TPER); Hoof lateral position (score 1 to 9) (HLPOS); Hoof rear position (score 1 to 9) (HRPOS); Milk yield (MY); Udder depth (scores 1 to 9) (UD); Milking time (MTmin).

The PRCOMP procedure of the $\mathrm{R}$ program was used (R DEVELOPMENT CORE TEAM, 2015) for analyzing the main components (MC) 
using the sample correlation matrix: the variables were standardized for mean zero and variance equal to one. We chose to use a correlation matrix instead of a covariance matrix to minimize possible discrepancies between the variances and to allow comparisons between eigenvectors in one component. The solution using the correlation matrix is recommended when the variables are measured in very different scales from one another, since this matrix is equivalent to the matrix of the standardized variables, considering that the analyzed characteristics are milk production, linear metric evaluations and area, and subjective scores.

The main component technique based on the correlation matrix consists of transforming a set of $p$ variables $\mathrm{X}_{1}, \mathrm{X}_{2}, \ldots, \mathrm{X}_{p}$ into a new set $\mathrm{Y}_{1}, \mathrm{Y}_{2}, \ldots$. , $\mathrm{Y}_{p}$, where $\mathrm{Y}$ 's have the following properties: each main component $(\mathrm{Y} i)$ is a linear combination of the standard variables $\left(\mathrm{X}_{j}\right)$, meaning that: $y_{i}=a_{i 1} x_{1}+a_{i 2}$ $x_{2}+\ldots+a_{i p} x_{p}=\sum_{\mathrm{j}=1}^{\mathrm{p}} a_{i j} x_{j}$; where are eigenvectors with $i=1,2, \ldots$, pe $\sum_{\mathrm{j}=1}^{\mathrm{p}} a^{2}{ }_{i j}$. The first major component $\left(\mathrm{Y}_{1}\right)$ is such that its variance is maximal among all linear combinations of $\mathrm{X}$. The second main component is uncorrelated with the first and has the second largest variance. Similarly, the other $p$ major components uncorrelated with each other are defined, so that: $\operatorname{Var}\left(\mathrm{y}_{1}\right) \geq \operatorname{Var}\left(\mathrm{y}_{2}\right) \geq \ldots \geq \operatorname{Var}\left(\mathrm{y}_{\mathrm{p}}\right)$. Each main component $Y i$ are related to $p$ eigenvalues ( $\lambda$ ) ordered so that $\lambda_{1} \geq \lambda_{2} \geq \ldots \geq \lambda_{\mathrm{p}}$. The linear combinations formed are uncorrelated: $\operatorname{Cov}\left(\mathrm{y}_{1}, \mathrm{y}_{2}\right)$ $=\operatorname{Cov}\left(\mathrm{y}_{1}, \mathrm{y}_{3}\right)=\ldots=\operatorname{Cov}\left(\mathrm{y}_{\mathrm{p}-1}, \mathrm{y}_{\mathrm{p}}\right)=0$. The relative importance of a major component was assessed by the percentage of total variance it explains, meaning that the percentage of its eigenvalue in relation to the total eigenvalues of all the components, which is given by: $y_{i}=\frac{\operatorname{Var}\left(y_{i}\right)}{\sum_{i=1}^{p} \operatorname{Var}\left(y_{i}\right)} * 100=\frac{\lambda_{i}}{\sum_{i=1}^{p} \lambda_{i}} * 100$ (HAIR JUNIOR, 2009).

The criterion for discarding variables was based on the recommendations of Jolliffe (1973), who suggests that the number of discarded variables should be equal the number of principal components whose variance (eigenvalue) is less than 0.7 ; and based on the suggestion by Hair Junior (2009), who considered that the variable that presents the largest coefficient in absolute value in the main component of smaller eigenvalue (lower variance) should be less important to explain the total variance, and therefore, subject to disposal. Thus, the discarding process consisted of considering the component corresponding to the lowest eigenvalue and rejecting the variable associated with the largest weighting coefficient (in absolute value). Then the next smaller component was evaluated. This process continued until the component associated with the eigenvalue less than 0.7 was considered.

\section{Results and Discussion}

The results obtained for the main components based on the correlation matrix, their respective eigenvalues, and percentages of the total variance explained by each component can be observed in Table 1.

The first major component, alone, accounted for approximately $30 \%$ of the total variance. When it was accumulated to the second, third, and fourth components, they jointly accounted for $60 \%$ of the total variance. The total variance values indicate that the first ten major components accounted for $85.35 \%$ of the total data variation. Pires et al. (2012) evaluated the morphometric variability of dairy goats and found that the first three major components accounted for about $99.51 \%$ of the total data variation.

According to Karacaören and Kadarmideen (2008), main components may be useful in reducing the number of measures to be evaluated, thereby avoiding problems with collinearity which is common in analyzing functional traits that are highly related. Thus, we continued with a criterion established by Jolliffe (1973) to select variables (when $\geq 0.7$ ); hence, it is assumed that thirteen of the 23 evaluated variables can be discarded. 
Table 1. Main components (MC), eigenvalues ( $\lambda \mathrm{i}$ ), percentage of variance explained by the components (\% VMC) and cumulative percentage of the evaluated traits.

\begin{tabular}{|c|c|c|c|}
\hline Main components & & $\% \mathrm{VMC}$ & $\%$ VMC (cumulative) \\
\hline $\mathrm{MC}_{1}$ & 4.59 & 29.94 & 29.94 \\
\hline $\mathrm{MC}_{2}$ & 3.02 & 15.12 & 45.06 \\
\hline $\mathrm{MC}_{3}$ & 2.17 & 8.43 & 53.49 \\
\hline $\mathrm{MC}_{4}$ & 1.75 & 6.59 & 60.08 \\
\hline $\mathrm{MC}_{5}$ & 1.61 & 5.98 & 66.06 \\
\hline $\mathrm{MC}_{6}$ & 1.51 & 5.54 & 71.60 \\
\hline $\mathrm{MC}_{7}$ & 1.25 & 4.44 & 76.04 \\
\hline $\mathrm{MC}_{8}$ & 1.08 & 3.51 & 79.55 \\
\hline $\mathrm{MC}_{9}$ & 0.95 & 3.00 & 82.55 \\
\hline $\mathrm{MC}_{10}$ & 0.90 & 2.80 & 85.35 \\
\hline $\mathrm{MC}_{11}$ & 0.66 & 2.12 & 87.47 \\
\hline $\mathrm{MC}_{12}$ & 0.51 & 2.10 & 89.57 \\
\hline $\mathrm{MC}_{13}$ & 0.49 & 1.94 & 91.51 \\
\hline $\mathrm{MC}_{14}$ & 0.42 & 1.53 & 93.04 \\
\hline $\mathrm{MC}_{15}$ & 0.40 & 1.25 & 94.29 \\
\hline $\mathrm{MC}_{16}$ & 0.33 & 1.13 & 95.42 \\
\hline $\mathrm{MC}_{17}$ & 0.27 & 1.07 & 96.49 \\
\hline $\mathrm{MC}_{18}$ & 0.23 & 1.00 & 97.49 \\
\hline $\mathrm{MC}_{19}$ & 0.22 & 0.97 & 98.46 \\
\hline $\mathrm{MC}_{20}$ & 0.15 & 0.64 & 99.10 \\
\hline $\mathrm{MC}_{21}$ & 0.13 & 0.55 & 99.65 \\
\hline $\mathrm{MC}_{22}$ & 0.06 & 0.28 & 99.93 \\
\hline $\mathrm{MC}_{23}$ & 0.02 & 0.07 & 100.00 \\
\hline
\end{tabular}

The reason for proposing the discard is that variables highly correlated to the major components of higher variance (eigenvalues lower than 0.7) represent practically insignificant variation, and therefore they do not contribute to selection. However, heritability estimates and genetic correlations must be taken into account, as the characteristics for discarding may have higher heritability than those with which they correlate favorably (FREITAS et al., 2010). This fact may cause the selection to be only based on the selected characteristics (meaning those present in the first ten main components) may lead to lower genetic gains.
The variables related to rump (RHT, RAG, RL, ILWI, ISWI), body (LEN), ubber (RHT), hoof (HLPOS) and milk yield (MY) are more important for explaining phenotypic variation in the evaluated Guzera cattle (Table 2).

The variables with less importance to explain the morphological variation in the Guzerá cattle were: FHT, FAG, FUH, FOL, REL, NAL, FOD, RED, AL, RUW, TPER, HRPOS, UD. These characteristics have a significant correlation with the others for being associated to components that explain a small proportion of linear trait variability in cattle, 
providing little or no additional information, thus being characterized by redundancy.

The main components associated with rump traits (height, length, angularity, ilium and ischium width) were those that contributed most to variation in linear trait types in the Guzerá breed.

Table 2. Weighting coefficients of the traits evaluated in Guzerá cattle with the main components discarded in order of minor importance.

\begin{tabular}{lcccccccccccc}
\hline Variable & MC1 & MC2 & MC3 & MC4 & MC5 & MC6 & MC7 & MC8 & MC9 & MC10 & MC11 & MC12 \\
\hline FHT & -0.41 & 0.07 & 0.06 & -0.05 & 0.13 & -0.04 & 0.23 & 0.04 & -0.14 & 0.18 & 0.01 & 0.01 \\
RHT & -0.41 & 0.11 & 0.05 & -0.04 & 0.12 & -0.01 & 0.17 & 0.08 & -0.18 & 0.12 & 0.03 & 0.04 \\
RHT & -0.15 & 0.24 & -0.16 & -0.18 & 0.31 & 0.26 & 0.18 & 0.17 & -0.02 & -0.31 & -0.19 & 0.20 \\
RAG & -0.11 & 0.00 & 0.22 & 0.36 & 0.21 & 0.22 & -0.22 & -0.40 & -0.14 & -0.25 & 0.10 & 0.26 \\
RHAG & 0.01 & 0.20 & 0.05 & -0.10 & -0.32 & 0.10 & 0.43 & -0.21 & 0.22 & 0.06 & 0.58 & 0.25 \\
FUH & -0.20 & 0.33 & 0.20 & -0.05 & -0.05 & 0.05 & -0.01 & -0.02 & 0.26 & -0.34 & 0.01 & 0.20 \\
FOL & 0.30 & 0.20 & 0.29 & 0.02 & -0.06 & 0.02 & 0.03 & 0.34 & -0.22 & -0.23 & 0.02 & 0.12 \\
RL & 0.07 & 0.34 & 0.16 & -0.23 & 0.04 & -0.33 & 0.07 & 0.22 & 0.06 & 0.17 & -0.04 & 0.03 \\
LEN & 0.06 & 0.28 & 0.02 & 0.10 & 0.47 & 0.18 & 0.07 & -0.20 & -0.23 & 0.13 & 0.10 & -0.34 \\
REL & 0.35 & 0.07 & 0.26 & -0.03 & -0.04 & 0.06 & 0.18 & 0.17 & -0.26 & -0.13 & -0.09 & -0.06 \\
NAL & 0.12 & -0.10 & 0.12 & 0.02 & -0.03 & 0.54 & 0.31 & 0.13 & 0.31 & 0.12 & -0.24 & -0.29 \\
FOD & 0.35 & 0.23 & 0.10 & 0.00 & 0.06 & -0.07 & -0.22 & -0.02 & -0.13 & -0.05 & 0.19 & -0.01 \\
RED & 0.34 & 0.01 & -0.05 & -0.12 & 0.15 & 0.08 & 0.08 & -0.26 & 0.14 & 0.22 & 0.25 & -0.07 \\
AL & -0.17 & 0.14 & 0.28 & 0.10 & -0.14 & 0.04 & -0.45 & 0.26 & 0.15 & 0.20 & 0.08 & 0.06 \\
ILWI & -0.06 & 0.39 & -0.02 & 0.30 & -0.10 & -0.21 & 0.23 & -0.11 & 0.12 & 0.00 & -0.22 & -0.23 \\
ISWI & 0.02 & 0.34 & 0.03 & 0.46 & -0.12 & 0.15 & -0.12 & -0.05 & 0.19 & 0.15 & -0.14 & -0.07 \\
RUW & 0.21 & 0.07 & -0.43 & 0.13 & 0.01 & 0.13 & -0.04 & 0.11 & 0.23 & 0.01 & -0.23 & 0.41 \\
TPER & 0.17 & 0.19 & -0.27 & -0.06 & 0.37 & -0.19 & -0.03 & -0.04 & 0.07 & 0.27 & -0.04 & 0.31 \\
LPOS & -0.01 & -0.12 & 0.39 & -0.30 & 0.24 & 0.29 & -0.14 & 0.00 & 0.19 & 0.18 & -0.07 & 0.22 \\
RPOS & -0.11 & 0.14 & -0.25 & -0.14 & 0.20 & 0.08 & -0.30 & 0.29 & 0.31 & -0.28 & 0.40 & -0.41 \\
PRLkg & 0.03 & -0.22 & 0.21 & 0.28 & 0.37 & -0.20 & 0.20 & 0.21 & 0.18 & 0.15 & 0.09 & 0.07 \\
UD & 0.04 & 0.02 & 0.26 & -0.31 & 0.08 & -0.31 & -0.07 & -0.41 & 0.35 & -0.19 & -0.33 & -0.14
\end{tabular}


Continuation...

\begin{tabular}{lccccccccccc}
\hline Variable & MC13 & MC14 & MC15 & MC16 & MC17 & MC18 & MC19 & MC20 & MC21 & MC22 & MC23 \\
\hline FHT & 0.02 & 0.12 & 0.26 & 0.12 & 0.10 & 0.02 & 0.13 & 0.26 & 0.01 & 0.18 & -0.69 \\
RHT & 0.09 & 0.03 & 0.27 & 0.11 & 0.18 & -0.02 & 0.00 & 0.35 & 0.02 & -0.22 & 0.65 \\
RHT & 0.37 & -0.18 & -0.20 & 0.06 & -0.11 & 0.13 & -0.35 & -0.13 & 0.20 & 0.22 & -0.01 \\
RAG & -0.13 & -0.10 & -0.12 & 0.30 & 0.32 & 0.22 & 0.01 & -0.05 & -0.24 & -0.01 & -0.04 \\
RHAG & 0.10 & 0.20 & -0.22 & 0.09 & -0.05 & 0.07 & 0.14 & -0.05 & 0.08 & 0.07 & 0.07 \\
FUH & -0.18 & -0.11 & 0.33 & -0.59 & -0.08 & -0.09 & 0.02 & -0.05 & -0.24 & -0.07 & -0.03 \\
FOL & 0.05 & 0.16 & 0.01 & 0.12 & 0.04 & 0.01 & 0.01 & 0.02 & 0.22 & -0.64 & -0.22 \\
RL & -0.34 & -0.40 & -0.41 & 0.15 & 0.11 & 0.06 & -0.02 & 0.19 & -0.27 & 0.05 & 0.00 \\
LEN & -0.17 & 0.04 & -0.16 & -0.21 & -0.43 & 0.15 & 0.28 & 0.04 & 0.12 & -0.07 & 0.05 \\
REL & 0.08 & 0.25 & 0.28 & 0.18 & -0.19 & 0.09 & 0.04 & -0.04 & -0.48 & 0.41 & 0.15 \\
NAL & -0.17 & 0.05 & -0.05 & -0.15 & 0.43 & 0.25 & -0.02 & 0.51 & 0.02 & -0.02 & 0.00 \\
FOD & 0.13 & -0.10 & 0.12 & -0.22 & 0.43 & -0.11 & 0.11 & 0.21 & 0.42 & 0.42 & 0.05 \\
RED & 0.14 & -0.42 & 0.44 & 0.14 & -0.09 & 0.04 & -0.37 & 0.08 & -0.11 & -0.21 & -0.11 \\
AL & 0.12 & 0.01 & 0.11 & 0.01 & -0.17 & 0.52 & -0.08 & -0.16 & 0.12 & 0.09 & 0.04 \\
ILWI & -0.10 & -0.11 & 0.24 & 0.31 & 0.10 & -0.12 & 0.07 & -0.06 & 0.23 & 0.03 & 0.05 \\
ISWI & 0.25 & 0.17 & -0.20 & 0.03 & -0.12 & -0.40 & -0.26 & 0.38 & -0.15 & 0.02 & -0.05 \\
RUW & -0.04 & -0.13 & 0.18 & 0.18 & -0.13 & 0.14 & 0.52 & 0.24 & 0.02 & -0.01 & 0.02 \\
TPER & -0.15 & 0.54 & 0.04 & -0.13 & 0.24 & 0.06 & -0.25 & -0.20 & -0.11 & -0.05 & 0.01 \\
LPOS & -0.21 & 0.05 & 0.04 & 0.25 & -0.14 & -0.50 & 0.09 & -0.13 & 0.19 & 0.09 & 0.06 \\
RPOS & 0.03 & 0.15 & 0.04 & 0.26 & 0.13 & -0.08 & 0.13 & -0.03 & -0.19 & -0.03 & -0.02 \\
PRLkg & 0.29 & -0.16 & -0.10 & -0.18 & 0.11 & -0.12 & 0.29 & -0.21 & -0.19 & -0.07 & 0.00 \\
UD & 0.48 & 0.21 & -0.04 & 0.10 & -0.02 & 0.24 & 0.14 & 0.20 & 0.06 & -0.08 & 0.01 \\
MTmin & -0.33 & 0.08 & 0.07 & 0.07 & -0.21 & 0.12 & -0.27 & 0.25 & 0.27 & 0.16 & 0.05 \\
\hline
\end{tabular}

FHT $=$ Fore udder height $(\mathrm{cm})$; RHT $=$ Rear udder height $(\mathrm{cm})$; RHT $=$ Rump height $(\mathrm{cm})$; RAG $=$ Rump angle (degrees); RHAG $=$ Rear hoof angle (degrees); FUH = Front udder height $(\mathrm{cm}) ; \mathrm{FOL}=$ Fore teat length $(\mathrm{cm}) ; \mathrm{RL}=$ Rump length (cm); LEN = Body length $(\mathrm{cm}) ; \mathrm{REL}=$ Rear teat length $(\mathrm{cm}) ; \mathrm{NAL}=$ Navel length $(\mathrm{cm}) ; \mathrm{FOD}=$ Fore teat diameter $(\mathrm{cm}) ;$ RED = Rear teat diameter $(\mathrm{cm})$; ILWI = Ilium width $(\mathrm{cm})$; ISWI = Ischium width $(\mathrm{cm})$; AL = Anterior Ligament (score 1 to 9); RUW = Rear udder width (cm); TPER = Thoracic perimeter (cm); LPOS = lateral position (score 1 to 9); RPOS = rear position (score 1 to 9); MY = Milk yield (kg); UD = Udder depth (score 1 to 9); MTmin

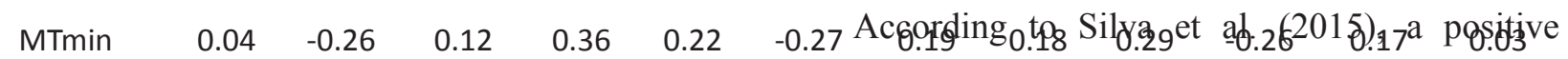

Rump width is influenced by the width between the ilium and ischium bones, which should be spaced out to facilitate delivery. According to Cerqueira et al. (2013), rump width in female cattle can reach $84 \%$ of its development at 21 months of age. In our study, cows from 7 different calving orders/parities were evaluated, a fact that probably contributed to the total variance of the components. correlation can be estimated between rump width and calving interval. Thus, the selection of large rumps may result in some correlated response in increased reproductive efficiency. However, Silva et al. (2015) draw attention to the negative genetic correlations between rump width and angle.

Body length, hoof angle, udder height and milk yield were also variables associated with components 
that explained a significant portion of linear trait variability in the cattle. The evaluated database had cows from different parities, and in these animals, maturity influences the body size and milk yield, which in turn has an influence on udder ligaments and on its height (LAGROTTA et al., 2010).
In observing the cluster analysis, using individual distribution according to main components (MC) 1 and 2 ( $45 \%$ of the total variance), we found that animals classified as young ( $1^{\text {st }}$ and $2^{\text {nd }}$ calving orders) and adults ( $3^{\text {rd }}$ to $7^{\text {th }}$ calving orders) were separated into two groups, but they had some similarity between them (Figure 1).

Figure 1. Projection of the variables evaluated in Guzerá cattle and grouped by main components of animals classified as adults and young.

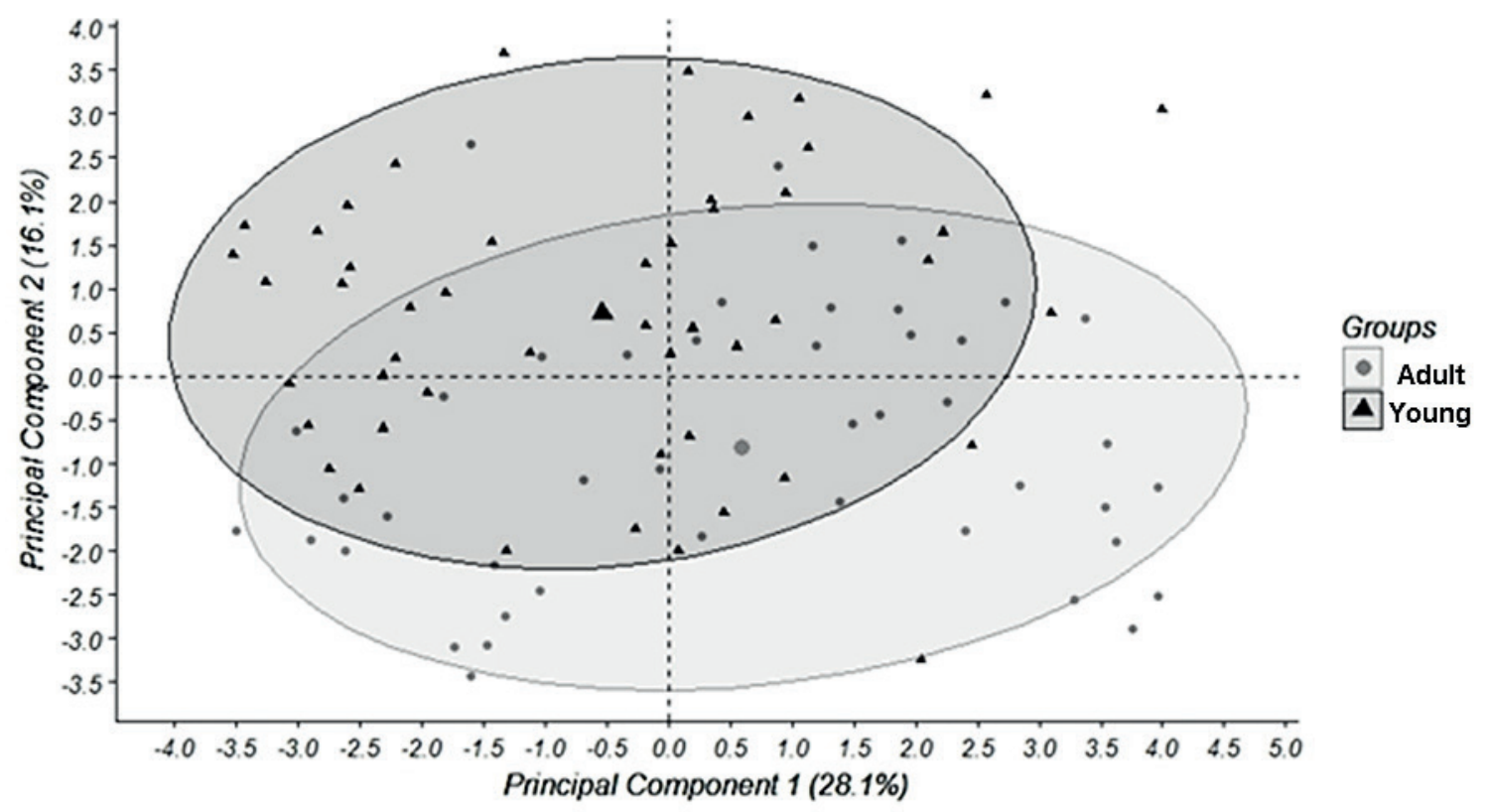

The similarity between animals classified as young and adult is related to the morphological type that they present. Young cows generally have shorter body lengths, narrower rumps, better udder ligaments and lower milk yields than adult cows (RANGEL et al., 2009; SOARES et al., 2009; GALVÃO JÚNIOR et al., 2010). However, it is unclear at what point (calving order) the changes that promote the greater variance of $\mathrm{MC} 1$ and $\mathrm{MC} 2$ occur.

The clustering analysis using MC1 and MC2 showed that animals classified according to the calving order were separated into 3 distinct groups; however, some animals showed some similarity between groups (Figure 2). 
Figure 2. Grouping of Guzerá cattle according to the calving order in relation to morphometric measurements and yield.

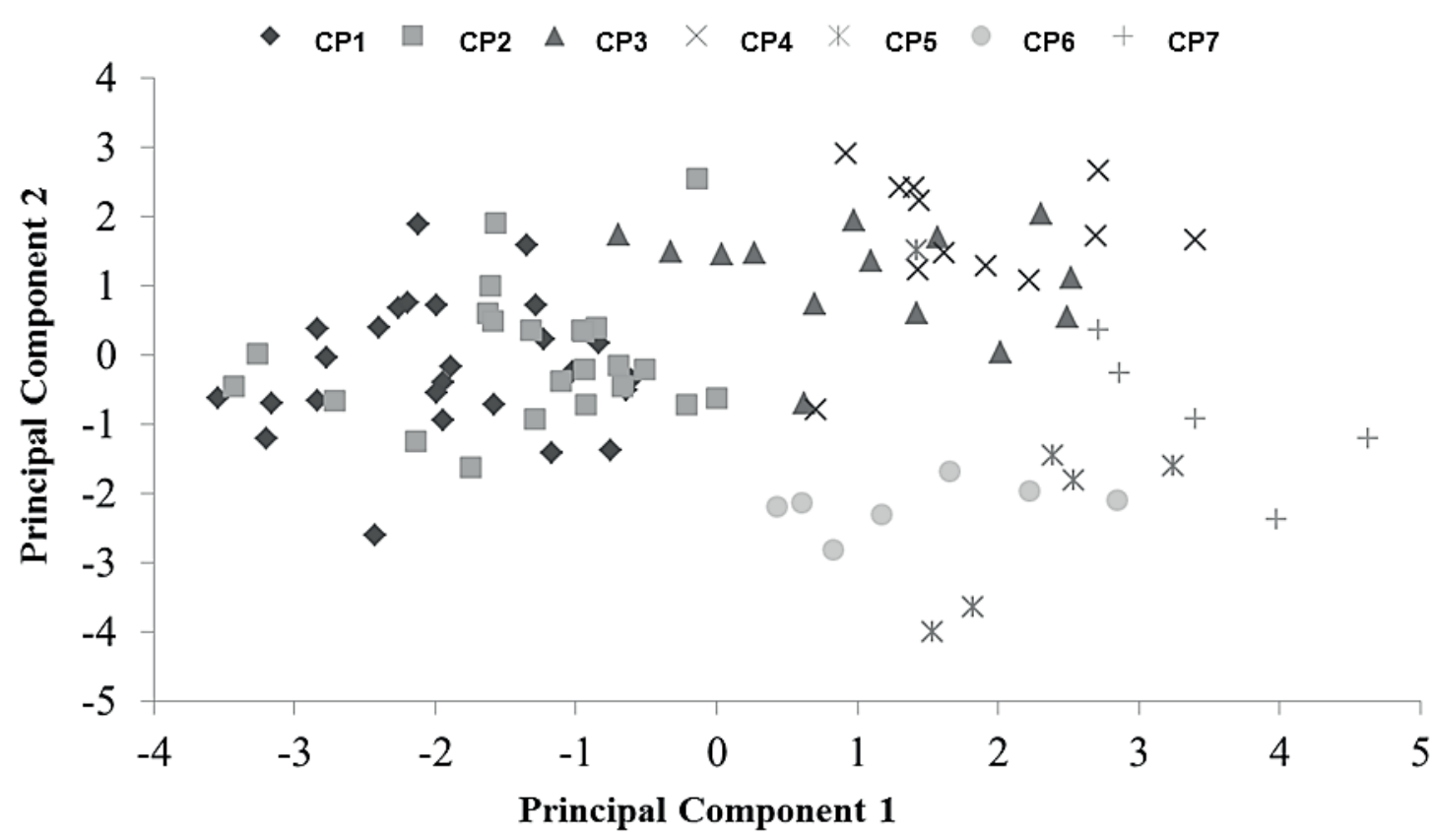

MC (1 and 2) used for graphic dispersion demonstrated that the cows of the first and second calving order are a homogeneous group, indicating that as they are very close, they have similar characteristics between them. Young cows $\left(1^{\text {st }}\right.$ and $2^{\text {nd }}$ calving order), therefore, diverge in their linear type traits from cows of the $3^{\text {rd }}$ to the $7^{\text {th }}$ calving order. Mota et al. (2015) evaluated zebu cattle, and observed that cows with morphometric differences have unique characteristics, such as body weight and morphometric measures that separate them into different groups.

The group comprising animals from the $5^{\text {th }}, 6^{\text {th }}$ and $7^{\text {th }}$ calving order present the greatest distancing of trait types when compared to the other groups. It is probable that cows in this group ( $5^{\text {th }}$ to $7^{\text {th }}$ calving order) are older cows (more than 09 years) and that this divergence in $\mathrm{MC}$ can be explained by these animals being a product of selection that prioritized other morphological characteristics (another linear type) in progeny. Malhado et al. (2010) documented a change in the Gir race phenotype in the Northeast of Brazil, and they attribute this to artificial selection.

\section{Conclusion}

Young cows from $1^{\text {st }}$ and $2^{\text {nd }}$ calving orders have lower body length, narrower rump, better udder ligaments and lower milk yield than adult Guzerá cows.

\section{References}

CERQUEIRA, J. O. L.; ARAÚJO, J. P. P.; VAZ, P. S.; CANTALAPIEDRA, J.; BLANCO-PENEDO, I.; NIZARIBEIRO, J. J. R. Relationship between zoometric measurements in Holstein-Friesian cow and cubicle size in dairy farms. International Journal of Morphology, Temuco, v. 31, n. 1, p. 55-63, 2013.

ESTEVES, A. M. C.; BERGMANN, J. A. G.; DURÃES, M. C.; COSTA, C. N.; SILVA, H. M. Correlações genéticas e fenotípicas entre características de tipo e produção de leite em bovinos da raça Holandesa. Arquivo Brasileiro de Medicina Veterinária e Zootecnia, Belo 
Horizonte, v. 56, n. 4, p. 529-535, 2004.

FREITAS, L. S.; SILVA, M. A.; VERNEQUE, R. S.; VALENTE, B. D.; CORREA, G. S.; FERREIRA, R. F.; PEIXOTO, M. G. C. D.; SANTOS, G. G. Avaliação da persistência na lactação da raça Guzerá, utilizando modelos de regressão aleatória. Arquivo Brasileiro de Medicina Veterinária e Zootecnia, Belo Horizonte, v. 62, n. 2, p. 401-408, 2010.

GALVÃO JÚNIOR, J. G. B.; RANGEL, A. H. N.; MEDEIROS, H. R.; SILVA, J. B. A.; AGUIAR, E. M.; MADRUGA, R. C.; LIMA JÚNIOR, D. M. Efeito da produção diária e da ordem de parto na composição físicoquímica do leite de vacas de raças zebuínas. Acta Veterinária Brasílica, Mossoró, v. 4, n. 1, p. 25-30, 2010.

HAIR JUNIOR, J. F.; BLACK, W. C.; BABIN, B. J.; ANDERSON, R. E.; TATHAM, R. L. Análise multivariada de dados. 6. ed. Porto Alegre: Bookman, 2009. 688 p.

HERRERA, L. G. G.; EL FARO, L.; ALBUQUERQUE, L. G.; TONHATI, H.; MACHADO, C. H. C. Parâmetros genéticos para produção de leite no dia do controle e para produção de leite até 305 dias nas primeiras lactações de vacas da raça Gir. Revista Brasileira de Zootecnia, Viçosa, MG, v. 37, n. 10, p. 1774-1780, 2008.

INSTITUTO BRASILEIRO DE GEOGRAFIA E ESTATÍSTICA - IBGE. Censo agropecuário. Rio de Janeiro: IBGE, 2015. 146 p.

JOLLIFFE, I. T. Discarding variables in a principal component analysis. II. Real data. Aplied Statistics, London, v. 22, n. 1, p. 21-31, 1973.

KARACAÖREN, B.; KADARMIDEEN, H. N. Principal component and clustering analysis of functional traits in swiss dairy cattle. Turkish Journal of Veterinary and Animal Sciences, Ankara, v. 32, n. 3, p. 163-171, 2008.

LAGROTTA, M. R.; EUCLYDES, R. F.; VERNEQUE, R. S.; SANTANA JÚNIOR, M. L.; PEREIRA, R. J.; TORRES, R. A. Relação entre características morfológicas e produção de leite em vacas da raça Gir. Pesquisa Agropecuária Brasileira, Brasília, v. 45, n. 4, p. 423-429, 2010.

LEÃO, G. F. M.; PIVATTO, D. R. D.; CARNIEL, H.; RODRIGUES, M. G. K.; BRAGA, R. A.; SILVA, M. R. H.; TEIXEIRA, P. P. M. Melhoramento genético em zebuínos leiteiros - uma revisão. Agropecuária Cientifica no Semiárido, Campina Grande, v. 9, n. 4, p. 9-14, 2013.

MALHADO, C. H. M.; CARNEIRO, P. L. S.; MALHADO, A. C. M.; MARTINS, J. A. M.; MARTINS FILHO, R.; BOZZI, R. Histórico da raça Gir registrada no Nordeste Brasileiro: melhoramento genético em características de crescimento e estrutura populacional. Ciência Rural, Santa Maria, v. 40, n. 6, p. 1385-1391, 2010 .

MARIZ, T. M. A.; GONZAGA NETO, S.; PIMENTA FILHO, E. P.; RIBEIRO, M. N.; GIVISIEZ, P. E. N.; CÂNDIDO, E. P.; BEZERRA, L. R.; LIMA JÚNIOR, D. M. Zoometria como ferramenta de caracterização morfoestrutural genética em fêmeas da raça Sindi no Brasil. Archivos de Zootecnia, Córdoba, v. 65, n. 249, p. 67-72, 2016.

MOTA, L. F. M.; MARIZ, T. M. A.; RIBEIRO, J. S.; SILVA, M. E. F.; LIMA JÚNIOR, D. M. Divergência morfométrica em bovinos Nelore em crescimento classificados para diferentes classes de frame size. Revista Caatinga, Mossoró, v. 28, n. 2, p. 117-125, 2015.

MUNIZ, C. A. S. D.; QUEIROZ, S. A.; MASCIOLI, A. S.; El FARO-ZADRA, L. Análise de componentes principais para características de crescimento em bovinos de corte. Semina: Ciências Agrárias, Londrina, v. 35, n. 3, p. 1569-1576, 2014.

PÉREZ-CABAL, M. A.; GARCÍA, C.; GONZÁLEZRECIO, O.; ALENDA, R. Genetic and phenotypic relationships among locomotion type traits, profit, production, longevity, and fertility in Spanish dairy cows. Journal of Dairy Science, Illinois, v. 89, n. 5, p. 1776-1783, 2006.

PIRES, L. C.; MACHADO, T. M.; ARAÚJO, A. M.; OLSON, T. A.; SILVA, J. B.; TORRES, R. A.; COSTA, M. S. Biometric variability of goat populations revealed by means of principal component analysis. Genetics and Molecular Biology, São Paulo, v. 35, n. 4, p. 777-782, 2012.

RANGEL,A.H.N.;GUEDES,P.L.C.;ALBUQUERQUE, R. P. F.; NOVAES, L. P.; LIMA JÚNIOR, D. M. Desempenho produtivo leiteiro de vacas Guzerá. Revista Verde de Agroecologia e Desenvolvimento Sustentável, Mossoró, v. 4, n. 1, p. 85-89, 2009.

R DEVELOPMENT CORE TEAM. R: a language and environment for statistical computing. R Foundation for Statistical Computing, Vienna, Austria, 2015. Available at: <www.R-project.org>. Accessed at: 21 mar. 2017.

RODRIGUEZ-MARTINEZ, H.; HULTGREN, J.; BÅGE, R.; BERGQVIST, A.-S.; SVENSSON, C.; BERGSTEN, C.; LIDFORS, L.; GUNNARSSON, S.; ALGERS, B.; EMANUELSON, U.; BERGLUND, B.; ANDERSSON, G.; HÅARD, M.; LINDHÉ, B.; STÅLHAMMAR, H.; GUSTAFSSON, H. Reproductive performance in highproducing dairy cows: can we sustain it under current practice? IVIS Reviews in Veterinary Medicine, Ithaca, v. 1, n. 108, p. 1-23, 2008. 
SILVA, R. P. A.; THALER NETO, A.; COBUCI, J. A.; VALLOTO, A. A.; HORST, J. A.; RIBAS NETO, P. G. Correlações genéticas entre algumas características de tipo e intervalo de partos em vacas da raça Holandesa. Arquivo Brasileiro de Medicina Veterinária e Zootecnia, Belo Horizonte, v. 67, n. 1, p. 166-172, 2015.

SOARES, G. V. M.; RANGEL, A. H. N.; AGUIAR, E. M.; MEDEIROS, H. R.; LIMA JÚNIOR, D. M. Influência da ordem de parto sobre a produção de leite de vacas zebuínas. Acta Veterinária Brasílica, Mossoró, v. 3, n. 2, p. 106-110, 2009.
VERNEQUE, R. S.; PANETTO, J. C. C.; TEIXEIRA, R. B.; PEIXOTO, M. G. C. D.; BRUNELI, F. A. T.; SANTOS, G. G.; MACHADO, M. A.; MARTINS, M. F.; SILVA, M. V. G. B.; ARBEX, W. A.; REIS, D. R. L.; GERALDO, C. C.; MACHADO, C. H. C.; PEREIRA. M. A.; VERCESI FILHO, A. E.; MACIEL, R. da S.; FERNANDES, A. R. Programa nacional de melhoramento do Gir Leiteiro - sumário brasileiro de touros - resultado do teste de progênie - $5^{a}$ prova de préseleção de touros - maio, 2014. Juiz de Fora: Embrapa Gado de Leite, 2014. 80 p. (Embrapa Gado de Leite. Documentos, 169). 